\title{
FIRST RECORD OF THE LEOPARD PLECO, PTERYGOPLICHTHYS GIBBICEPS (ACTINOPTERYGII, LORICARIIDAE) IN THE BRDA RIVER IN THE CENTRE OF BYDGOSZCZ (NORTHERN POLAND)
}

\author{
Sławomir KESZKA ${ }^{1 *}$, Remigiusz PANICZ ${ }^{2}$, and Adam TAŃSKI ${ }^{3}$ \\ ${ }^{1}$ Division of Fish Systematics, ${ }^{2}$ Division of Aquaculture, \\ ${ }^{3}$ Division of Fish Anatomy and Embryology, Faculty of Food Sciences and Fisheries, \\ Agricultural University of Szczecin, Poland
}

Keszka S., Panicz R., Tański A. 2008. First record of the leopard pleco, Pterygoplichthys gibbiceps (Actinopterygii, Loricariidae) in the Brda River in the centre of Bydgoszcz (northern Poland). Acta Ichthyol. Piscat. 38 (2): 135-138.

\begin{abstract}
The presently reported finding of leopard pleco, Pterygoplichthys gibbiceps (Kner, 1854) (Loricariidae), in open waters of the Brda River in the centre of Bydgoszcz, constitutes the first record of a southAmerican loricariid fish species in Poland. The specimen found is described and illustrated. The finding is discussed in association with other alien species sightings in Poland. The described leopard pleco is possibly the next example of an emerging alien fish species in inland Polish waters.
\end{abstract}

Keywords: fish, leopard pleco, exotic species, alien species, inland waters, Poland

The leopard pleco, Pterygoplichthys gibbiceps (Kner, $1854)$, is a demersal species that belongs to Loricariidae, the largest (684 species and 92 genera) family of the order Siluriformes (cf. Nelson 2006). This species naturally inhabits inland waters of South America, mainly in the middle stretch and the upstream section of the Orinoco and Amazon rivers that flow through Venezuela, Brazil, and Peru (Armbruster and Page 1993, Weber 2003). The main food source of the nocturnal Leopard pleco are algae. Its favourite water temperature range is $23-27^{\circ} \mathrm{C}$, acceptable $\mathrm{pH}$ value is between 6 and 8 , and water hardness from 5 to $19 \mathrm{dH}$. This species has high market value as an aquarium fish and can be found in aquaria worldwide.

On 11 September 2006, Mr. Adam Mendelewski, a local angler on the Brda River, captured a specimen of an unknown fish from the river near the Siedlecka Street (Bydgoszcz) and brought it to the attention of the Polish Anglers Association. The fish was caught 1.9-2.1 m below the water surface and $7 \mathrm{~m}$ from the shore. The water temperature that day was $7^{\circ} \mathrm{C}$ and a Dendrobena (composting worm) was used as a natural bait. The specimen weighing $732 \mathrm{~g}$ was identified as a representative of genus Pterygoplichthys Gill 1858 (=Glyptopterichthys) using taxonomic keys of Weber (1992) and Page et al. (1996) (Fig.1). Histological analyses revealed immature male gonads. The digestive tract was filled with fragments of undigested leaves. According to Weber (1991, 1992) species of Pterygoplichthys are large loricariids that have large dorsal fins with nine or more (usually 10+) dorsal-fin rays. In the laboratory of the Division of Fish Systematics morphological measurements were made to the nearest 0.1 with the use of digital calliper. The colour pattern was generally dark brown with either darker spots or lighter spots or vermiculations. Abdomen almost completely covered in small plates (Fig. 2). Tail forked with the lower lobe longer than the upper. Five rows of plates on the abdomen side. The Pterygoplichthys gibbiceps group (Glyptopterichthys sensu Weber 1991, 1992 excluding P. punctatus) is easily recognized by having a large supraoccipital crest (Armbruster 2004) (Fig. 1).

Loricariids are commonly used for removing algae from the glass walls of fish tanks worldwide. Some of them escape on their own, but in some cases they are also deliberately released by people to local bodies of water. One of such cases was reported by Chavez et al. (2006) from the Philippines. According to Pimentel et al. (2005), 138 alien fish species have been introduced into open waters in the USA. In Poland, the increasing number of alien species sightings attracts attention of scientists, but recently also institutions responsible for the environment-

\footnotetext{
* Correspondence: Dr Sławomir Keszka, Zakład Systematyki Ryb, Wydział Nauk o Żywności i Rybactwa, Akademia Rolnicza w Szczecinie, ul. Kazimierza Królewicza 4, 71-550 Szczecin, Poland, phone +48914231061, e-mail: keszka@fish.ar.szczecin.pl
} 


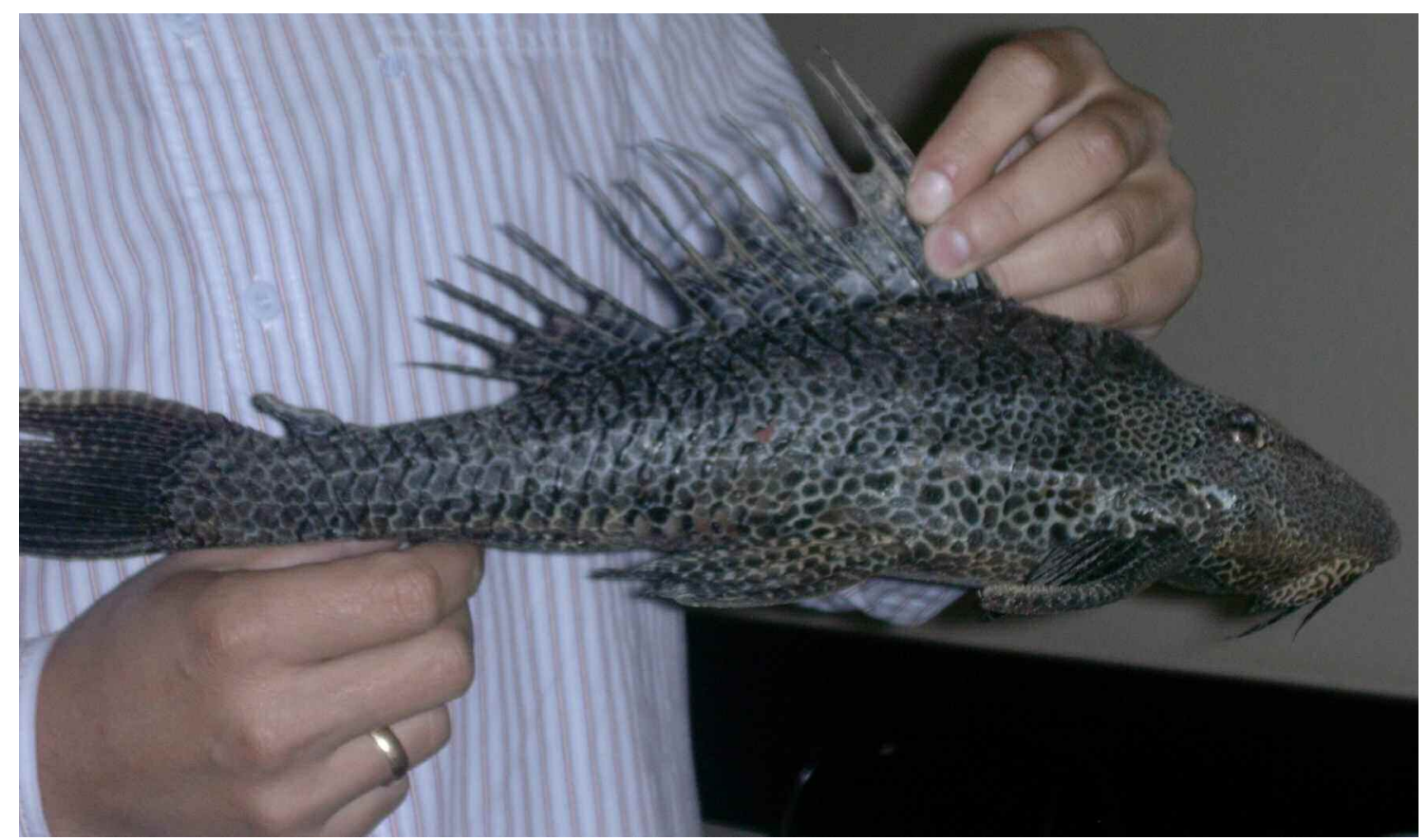

Fig. 1. Leopard pleco, Pterigoplichthys gibbiceps, lateral view

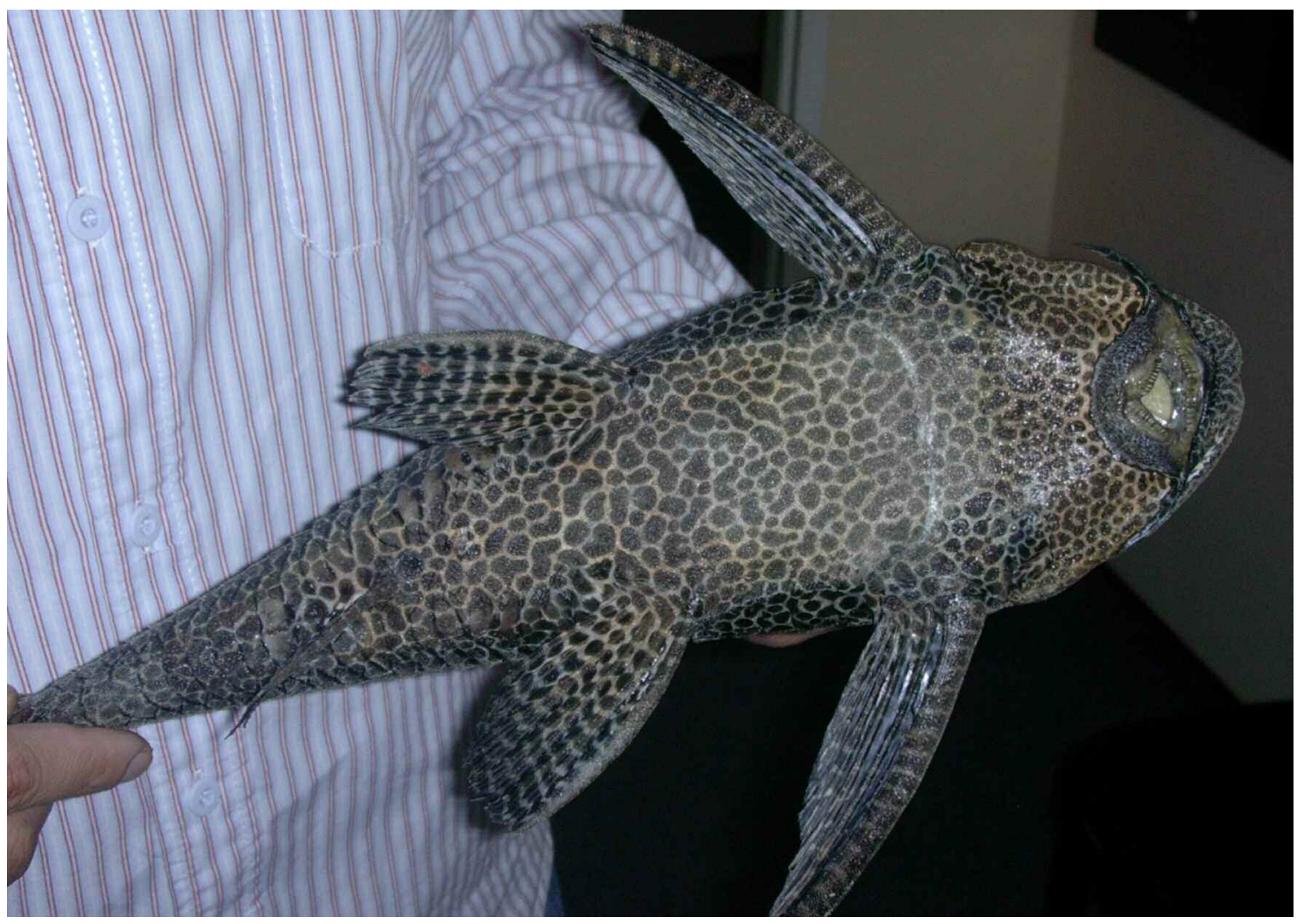

Fig. 2. Leopard pleco, Pterigoplichthys gibbiceps, ventral view

related issues. The official report from a large-scale (country-wide) inventory of fisheries usage (and potential) of inland waters (Anonymous 2001, p. 22) stated: "...the revealed cases of introducing alien fish species into Polish inland waters are highly disturbing. At present, as determined by this inventory, in addition to 79 native fish species there are additional 23 alien fish species that have been introduced. During this full-scale investigation inspectors revealed individual farms rearing alien species without necessary permissions from the Ministry of Agriculture and Rural Development..."

The above-mentioned 23 alien species are in general freshwater ones, described in the book "Freshwater Fishes of Poland" (Brylińska 2000). Some 30\% of all Polish 
freshwater fishes are introduced species. This situation, in Polish open waters, dynamically changes, because of the increasing number of intentional introductions and the increasing number of escapees from exotic species farms.

In the mid 20th century fishes like grass carp, Ctenopharyngodon idella (Valenciennes, 1844); silver carp, Hypophthalmichthys molitrix (Valenciennes, 1844); and bighead carp, Aristichthys nobilis (Richardson, 1845), were unintentionally introduced into Polish waters. The development and amelioration of culture technology in the 1990s resulted in several cases of acipenseriform fishes caught in open waters: Siberian sturgeon, Acipenser baerii Brandt, 1869; Russian sturgeon, Acipenser gueldenstaedtii Brandt et Ratzeburg, 1833; starry sturgeon, Acipenser stellatus Pallas, 1771; and Mississippi paddlefish, Polyodon spathula (Walbaum, 1792) (cf. Keszka and Stepanowska 1997, Krzykawski et. al. 2001, Keszka and Heese 2003). Also other non-acipenseriform species, such as stone moroko, Pseudorasbora parva (Temminck et Schlegel, 1846), appeared in Polish inland waters (Witkowski 1991). It is very likely that the eastern mudminnow, Umbra pygmaea (DeKay, 1842), and the exotic pirapitinga, Piaractus brachypomus (Cuvier, 1818) have been introduced by aquarists (Witkowski et al. 1995, Kostrzewa 1998, Więcaszek et al. 2007). The presently reported leopard pleco was probably released into the Brda River by aquarists as well. Another source of the introductions may be escapees from exotic fish farms. In Poland, the most convenient sites for such farms are the cooling water discharge outlets of power plants (Mr. Tomasz Jąkalski, personal communication). It is obvious that fish are more likely to escape from a cage culture than from a pond. It is estimated, however, that only few out of numerous alien fish species reported from Poland, can be considered invasive, because only some of them are capable of having a fertile offspring and of settling new places. Highly spectacular are cases of species that came from foreign river estuaries. A good example can be the Chinese sleeper, Perccottus glenii Dybowski, 1877, that has been continuously present in Polish waters since 1990 (Kostrzewa et al. 2004).

There has been an increase of the number of new alien fish species during the last 40 years, caused by rising human populations, migration, and environmental changes. Moreover, the globalization of the economy and the worldwide exchange of goods have also influenced exotic fish introductions to open waters in many countries (Bryan 1996). Research projects focused on invasive species are extremely important not only in the faunistic point of view but also in terms of potential threats for ecosystems, brought by alien fish species. A good example was a new species of an Amazon monogenean (Mymarothecium viatorum) described from the gills of a pirapitinga, $P$. brachypomus (an alien species to Polish waters), caught in the warm-water discharge canal of the Pomorzany Power Plant in Szczecin (Boeger et al. 2002). Parasites of ornamental fishes, known for their wider host specificity, may acquire new host species, among free-liv- ing native fishes, in a newly invaded territory (body of water) (King and Cable 2007). Also, a relatively harmless parasite, upon transferring to a new territory may prove disastrous for the same fish species, without innate immunity to this particular pathogen. A good example is Gyrodactylus salaris (Monogenea) transferred from the Baltic Sea and whipping out entire populations of naïve Atlantic salmon from Norwegian rivers (Bakke et al. 2004). Another spectacular example can be the Asian nematode Anguillicola crassus infecting European eel (Taraschewski et al. 1998)

Introduced fishes must be considered competitors with regard to the utilisation of the habitat and food resources as well as to the potential risk of interference with the gene pool of the native species (Gessner et al. 1999).

The presently described leopard pleco specimen has been deposited at the Museum of Natural History, Wrocław University (MNHWU-FC 083 793). Moreover, a DNA sample was isolated from the muscle tissue in order to perform further genetic analyses.

\section{ACKNOWLEDGEMENTS}

Authors are thankful to Mr. Adam Mendelewski and Mr. Arkadiusz Nicpoń, BScEng (Polish Anglers Association, Bydgoszcz) for their help in collecting and preservation of the specimen.

\section{REFERENCES}

Anonymous 2001. Informacja o wynikach kontroli wykorzystania wód śródlądowych do gospodarki rybackiej. [Information about results of the control of the usage of inland waters for fisheries.] Najwyższa Izba Kontroli, Departament Rolnictwa i Gospodarki Żywnościowej. DRiGŻ 41007-2000 Nr ewid. 118/2001/P/00/111/DRZ. [In Polish.]

Armbruster J.W. 2004. Phylogenetic relationships of the suckermouth armoured catfishes (Loricariidae) with emphasis on the Hypostominae and the Ancistrinae. Zoological Journal of the Linnean Society 141: 1-80.

Armbruster J.W., Page L.M. 1996. Redescription of Aphanotorulus (Teleostei: Loricariidae) with description of one new species, A. ammophilus, from the Río Orinoco basin. Copeia 1996: 379-389.

Chavez J.M., de la Paz R.M., Manohar S.K., Pagulayan R.C., Carandang VI J.R. 2006. New Philippine record of south American sailfin catfishes (Pisces: Loricariidae). Zootaxa 1109: 57-68.

Bakke T.A., Nilsen K.B., Shinn A.P. 2004. Chaetotaxy applied to Norwegian Gyrodactylus salaris Malmberg, 1957 (Monogenea) clades and related species from salmonids. Folia Parasitologica 51: 253-261.

Boeger W.A., Piasecki W., Sobecka E. 2002. Neotropical Monogenoidea Mymarothecium viatorum sp. $\mathrm{n}$. (Ancyrocephalinae) from the gills of Piaractus brachypomus (Serrasalmidae, Teleostei) captured in a warm-water canal of a power plant in Szczecin, Poland. Acta Ichthyol. Piscat 32: 157-161.

Bryan R.T. 1996. Alien species and emerging infectious diseases: past lessons and future applications. Pp. 74-80. 
In: Sandlund G.T., Schel P.J., Viken A. (eds.) Proceedings of the Norway/UN Conference on Alien Species, July 1-5 1996, Norwegian Institute for Nature Research, Trondheim, Norway.

Brylińska M. (ed.) 2000. Ryby słodkowodne Polski. [The freshwater fishes of Poland.] Wydawnictwo Naukowe PWN, Warszawa. [In Polish.]

Gessner J., Debus L., Filipiak J., Spratte S., Skóra K.E., Arndt G.M. 1999. Development of sturgeon catches in German and adjacent waters since 1980. Journal of Applied Ichthyology 15: 136-141.

Keszka S., Heese T. 2003. Occurrence of exotic Russian sturgeons, Acipenser gueldenstaedtii Brandt et Ratzeburg, 1833 (Actinopterygii: Acipenseridae) in the Baltic Sea. Acta Ichthyol. Piscat: 33: 178-183.

Keszka S., Stepanowska K. 1997. Pojawienie się jesiotrów (Acipenseridae) w estuarium Odry. [First records of sturgeons (Acipenseridae) in the Oder River estuary.] Komunikaty Rybackie 1997 (2): 11-12. [In Polish.]

King T.A., Cable J. 2007. Experimental infections of the monogenean Gyrodactylus turnbulli indicate that it is not a strict specialist. International Journal for Parasitology 37: 663-672.

Kostrzewa J. 1998. Nowe stanowiska Umbra pygmaea De Key, $1842 \mathrm{w}$ dorzeczu Odry. [New location of Umbra pygmaea De Key, 1842 in Odra River drainage.] Przegląd Zoologiczny 42: 237-240. [In Polish.]

Kostrzewa J., Grabowski M., Zięba G. 2004. Nowe inwazyjne gatunki ryb w wodach Polski. [New invasive fish species in Polish waters.] Archives of Polish Fisheries 12 (Supplement 2): 21-34. [In Polish.]

Krzykawski S., Więcaszek B., Keszka S. 2001. The taxonomic revue [sic] of representatives of the extremely rare species in Polish waters collected within 1993-1999. Folia Universitatis Agriculturae Stettinensis, Piscaria 2001 (218/28): 53-62.

Nelson, J.S. 2006. Fishes of the world. 4th edn. John Wiley and Sons, Hoboken NJ.

Page L.M., Armbruster J.W., Sabaj M.H. 1996. Redescription of Glyptoperichthys scrophus (Cope), a loricariid catfish from Peru. Ichthyological Exploration of Freshwaters 7: 185-191.
Pimentel D., Zuniga R., Morrison D. 2005. Update on the environmental and economic costs associated with alieninvasive species in the United States. Ecological Economics 52: $273-288$.

Taraschewski H., Knopf K., Wurtz J. 1998. Anguillicola crassus (nematodes) in the European eel: pathogenicity and immune biology. Parasitology International 47 (Supplement 1): 201-201.

Weber C. 1991. Nouveaux taxa dans Pterygoplichthys sensu lato (Pisces, Siluriformes. Loricariidae). Revue Suisse de Zoologie 98: 637-643.

Weber C. 1992. Révision du genre Pterygoplichthys sensu lato (Pisces, Siluriformes, Loricariidae). Revue Française di Aquariologie Herpétologie 19: 1-36.

Weber C. 2003. Hypostominae. Pp. 351-372. In: Reis R.E., Kullander S.O., Ferraris C.J.jr., (eds.) Check list of the freshwater fishes of South and Central America. Edipucrs, Porto Alegre, Brazil.

Więcaszek B., Keszka S., Antoszek J. 2007. Pirapitinga (Piaractus brachypomus Cuvier, 1818) - an alien species in the natural water basins within the Szczecin area (NW Poland). P. 20. In: Buj I., Zanella L., Mrakovcic M. (eds.) Book of abstracts XII European Congress of Ichthyology. 9-13 September 2007 Cavtat (Dubrovnik), Croatia. The European Ichthyological Society, Zagreb.

Witkowski A. 1991. Pseudorasbora parva (Schlegel, 1842) (Cyprinidae, Gobioninae) nowy gatunek w polskiej ichtiofaunie. [Pseudorasbora parva (Schlegel. 1842) (Cyprinidae, Gobioninae) a new species for Polish ichthyofauna.] Przegląd Zoologiczny 35: 323-331. [In Polish.]

Witkowski A., Kuśnierz J., Kotusz J. 1995. Umbra pygmaea De Key, 1842 (Osteichthyes, Umbridae) nowy introdukowany gatunek ryb w polskiej ichtiofaunie. [Umbra pygmaea De Key, 1842 (Osteichthyes, Umbridae) a newly introduced fish species in Polish ichthyofauna.] Przegląd Zoologiczny 39: 281-286. [In Polish.]

Received: 24 July 2008

Accepted: 31 October 2008 Published electronically: 15 December 2008 